\title{
Apocrine Hidrocystoma on the Penis: Report of a Case and Review of the Previous Cases
}

\author{
Jeong Won Jo, Jung Wook Yang ${ }^{1}$, Do Seon Jeong \\ Departments of Dermatology and ${ }^{1}$ Pathology, Gyeongsang National University School of Medicine, Jinju, South Korea
}

Apocrine hidrocystoma, also called apocrine cystadenoma, is a benign cystic tumor-like lesion that arises from the proliferation of apocrine glands. Clinically, it usually occurs singly as a unilocular or multilocular, dome-shaped translucent cyst. Histologically, it appears as unilocular or multilocular cysts composed of an inner layer of single or double layer of secretory columnar epithelium with decapitation secretion lying above an outer myoepithelial cell layer. Apocrine hidrocystomas mostly occur within the head and neck region and involvement of genitalia is extremely rare. This paper emphasizes the importance of considering the differential diagnosis of a genital cystic lesion. Herein, we report a case of apocrine hidrocystoma occurring in the penis and compare the clinicopathological characteristics of apocrine hidrocystoma in genitalia with the previous cases. (Ann Dermatol 31(4) $442 \sim 445,2019$ )

\section{-Keywords-}

Apocrine glands, Hidrocystoma, Penis

\section{INTRODUCTION}

Hidrocystomas are rare, benign, cystic lesions of sweat gland resulting from proliferation of the apocrine secretory coil or eccrine duct ${ }^{1}$. Apocrine hidrocystoma, also called apocrine cystadenoma, is a benign cystic tumor-like lesion usually presenting as a solitary translucent nodule of cystic consistency ${ }^{2}$. The apocrine glands are most frequent in the axilla, external auditory canal, eyelids, and on the nipple, and it is not surprising that most apocrine hidrocystomas occur within the head and neck region ${ }^{3}$. However, involvement of genitalia is extremely rare and a few cases have been reported ${ }^{3-13}$.

\section{CASE REPORT}

A 39-year-old male patient presented with a mass on the penis that had been growing slowly for 1 year (Fig. 1). On clinical examination, about $4.0 \times 0.3 \mathrm{~cm}$, serpiginous cyst was found. It was not tender, the skin over the cyst was normal and it was not attached to the penile shaft. There were no signs of pain, tenderness, pruritus, or other symptoms. His past medical history was irrelevant. He denied traumatism and risky or vigorous sexual activities. Patient was taken up for surgery and excision of the mass was performed under local anaesthesia. Histological evaluation revealed the presence of a cyst in the dermis (Fig. 2). The inner surface of the cyst and the papillary projections are lined by a row of columnar secretory cells of variable height showing decapitation secretion indicative of apocrine secretion. Peripheral to the layer of secretory cells are elongated myoepithelial cells. Immunohistochemically, the inner cells show cytoplasmic stains for cytokeratin (CK) 7 and outer cells show nuclear stains for p63, respectively. CK20 and carcinoembryonic antigen (CEA) are negative in both cells. A diagnosis of apocrine hidrocystoma of the 
penis was established.

\section{DISCUSSION}

Apocrine hidrocystoma is a benign cyst tumor that arises from the proliferation of apocrine glands in adults be-

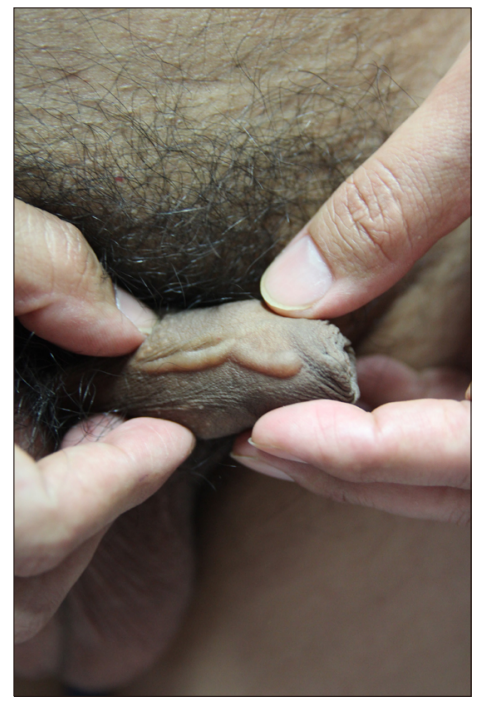

Fig. 1. Clinical photograph of serpiginous cyst measuring about $4.0 \times 0.3 \mathrm{~cm}$ on the penile shaft. tween 30 and 70 years of age ${ }^{11}$. The pathophysiology of hidrocystomas is unclear, though many theories exist. The occlusion or blockage of the sweat duct apparatus, which results in the retention of sweat, and a dilated cystic structure, are considered to be plausible causes ${ }^{14}$. The apocrine glands are most frequent in the axilla, external auditory canal, eyelids, and on the nipple, and it is not surprising that most apocrine hidrocystomas occur within the head and neck region ${ }^{3}$. However, involvement of genitalia is extremely rare, and to date twelve cases have been reported (Table 1$)^{3-13}$.

Clinically, Apocrine hidrocystoma usually occurs singly as a unilocular or multilocular, dome-shaped translucent cyst, that is either flesh colored or bluish black and ranges from a few millimeters to more than $1 \mathrm{~cm}$ in diameter ${ }^{3}$. Histopathologically, apocrine hidrocystoma appears as unilocular or multilocular cysts composed of an inner layer of single or double layer of secretory columnar epithelium with decapitation secretion lying above an outer myoepithelial cell layer ${ }^{15}$. Immunohistochemically, apocrine hidrocystoma is positive for CK7, CK18 and gross cystic disease fluid protein 15 in the inner layer of epithelium, and alpha-smooth muscle actin and p63 in the outer myoepithelial cells ${ }^{1,16}$.

For cystic lesions in genitalia, the differential diagnosis also includes congenital cysts of the median raphae, eccrine
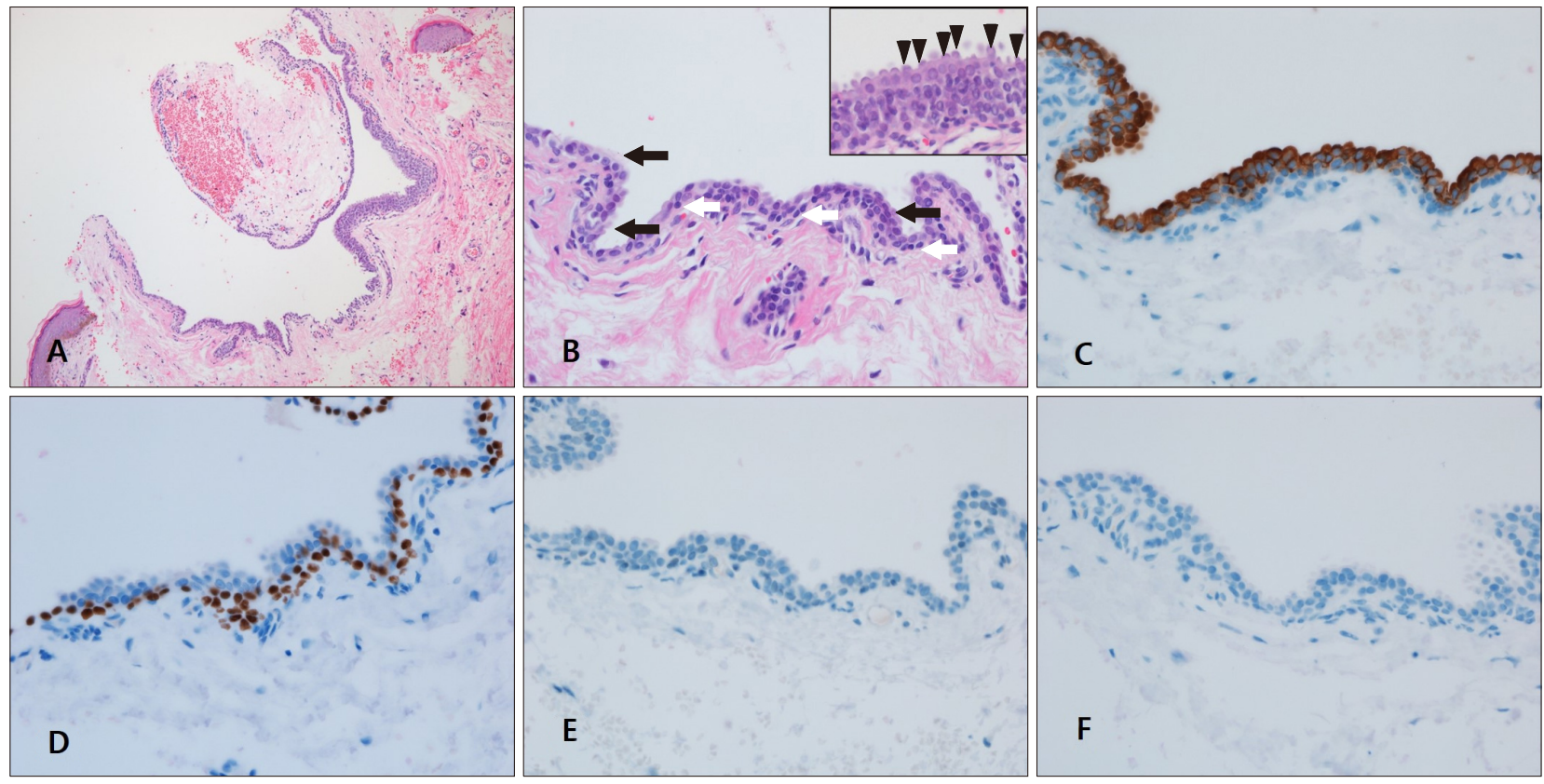

Fig. 2. Microscopic feature of apocrine hidrocystoma. (A) A cystic lesion in dermis is lined by (B) double layers of epithelial cells: an inner layer of cuboidal cells (black arrows) with apical snout (black arrowheads) and an outer layer of flattened cells (white arrows) with relatively small dark nucleus. The inner cells show cytoplasmic stains for (C) cytokeratin (CK) 7 and outer cells show nuclear stains for (D) p63, respectively. (E) CK20 and (F) carcinoembryonic antigen (CEA) are negative in both cells. (A) H\&E, $\times 100,(B)$ $\mathrm{H} \& \mathrm{E}, \times 400,(\mathrm{C}) \mathrm{CK} 7, \times 400$, (D) $\mathrm{p} 63, \times 400$, (E) CK20, $\times 400$, (F) CEA $\times 400$. 
Table 1. Summary of clinicopathological characteristics of previous cases of apocrine hidrocystomas involving the genitalia

\begin{tabular}{|c|c|c|c|c|c|c|}
\hline Author & Age $(y r)$ & Sex & Location & Clinical feature & Number/size & Immunohistochemistry finding \\
\hline \multirow[t]{2}{*}{ Ahmed et al. ${ }^{4}$} & 29 & Male & Prepuce & A small cyst & $1 / 1 \mathrm{~cm}$ & $\begin{array}{l}\operatorname{PAS}(+), \text { D-PAS }(+), \operatorname{PTAH}(-) \\
\text { Heidenhain's iron haematoxylin }(-)\end{array}$ \\
\hline & 56 & Male & Prepuce & A cyst & $1 /-$ & $\begin{array}{l}\operatorname{PAS}(+), \text { D-PAS }(+), \operatorname{PTAH}(-), \\
\text { Heidenhain's iron haematoxylin }(-)\end{array}$ \\
\hline Powell et al. ${ }^{5}$ & 23 & Male & Penile shaft & $\begin{array}{l}\text { Flesh colored with a slight } \\
\text { bluish hue }\end{array}$ & $1 / 0.4 \times 0.5 \mathrm{~cm}$ & $\operatorname{PAS}(+)$, D-PAS $(+)$ \\
\hline de Dulanto et al. ${ }^{6}$ & 49 & Male & Prepuce & $\begin{array}{l}\text { Hard tumor covered with } \\
\text { normal skin }\end{array}$ & $1 / 3 \mathrm{~cm}$ & $\begin{array}{l}\operatorname{PAS}(+) \text {, D-PAS }(+) \text {, Red with alcian } \\
\text { blue staining }\end{array}$ \\
\hline Flessati et al. $^{7}$ & 8 & Male & Scrotum & $\begin{array}{l}\text { Numerous brownish cyst } \\
\text { formation along the } \\
\text { midline }\end{array}$ & $4 / 0.3 \sim 1.0 \mathrm{~cm}$ & $\operatorname{PAS}(+)$ \\
\hline Glusac et al. ${ }^{8}$ & 34 & Female & Labium major & $\begin{array}{l}\text { Freely mobile, fluctuant, } \\
\text { dermal nodule }\end{array}$ & $1 / 3.0 \mathrm{~cm}$ & $\begin{array}{l}\text { D-PAS }(+), \text { GCDFP-15(+), CEA }(-) \text {, } \\
\text { factor XIIIa }(-) \text {, Blue granules with } \\
\text { Prussian blue staining }\end{array}$ \\
\hline Mataix et al. ${ }^{9}$ & 35 & Male & Penile shaft & Translucent nodular lesion & $1 / 1.5 \mathrm{~cm}$ & NA \\
\hline Samplaski et al. ${ }^{3}$ & 6 & Male & Glans penis & $\begin{array}{l}\text { Painless, glanular cystic } \\
\text { mass }\end{array}$ & $1 / 3 \times 3 \mathrm{~mm}$ & NA \\
\hline Liu et al. ${ }^{10}$ & 25 & Male & Penile shaft & $\begin{array}{l}\text { Dome-shaped translucent } \\
\text { nodule }\end{array}$ & $1 / 1.2 \mathrm{~cm}$ & $\mathrm{P} 63(+)$ \\
\hline López et al. ${ }^{11}$ & 40 & Male & Penile shaft & $\begin{array}{l}\text { Painless, well-defined, } \\
\text { serpinginous mass }\end{array}$ & $1 / 3 \times 0.5 \mathrm{~cm}$ & NA \\
\hline Park et al. ${ }^{12}$ & 4 & Male & Scrotum & $\begin{array}{l}\text { Multiple linear arranged } \\
\text { skin-coloured papules }\end{array}$ & NA & $\operatorname{PAS}(+)$ \\
\hline Taylor et al. ${ }^{13}$ & 16 & Male & $\begin{array}{l}\text { Ventral urethral } \\
\text { orifice }\end{array}$ & $\begin{array}{l}\text { Wide bluish translucent } \\
\text { cyst }\end{array}$ & $1 / 0.8 \mathrm{~cm}$ & $\begin{array}{l}\text { D-PAS }(+), \operatorname{GCDFP}-15(+), \text { p63(+), } \\
\text { S-100(-) }\end{array}$ \\
\hline Our case & 39 & Male & Penile shaft & Serpiginous cyst & $1 / 4 \times 0.3 \mathrm{~cm}$ & $\operatorname{CK} 7(+), \operatorname{p} 63(+), \operatorname{CK} 20(-), \operatorname{CEA}(-)$ \\
\hline
\end{tabular}

PAS: periodic acid-Schiff stain, D-PAS: diastase resistant-periodic acid-Schiff, PTAH: phosphotungstic acid haematoxylin, GCDFP-15: gross cystic disease fluid protein 15, CEA: carcinoembryonic antigen, CK: cytokeratin, NA: not assessed.

hidrocystoma, sclerosing lymphangitis, and acquired lymphangioma ${ }^{9}$. Especially, differentiating apocrine hidrocystoma from median raphe cyst (MRC) could be difficult. In the past, some reports of apocrine hidrocystoma on the penis represented $\mathrm{MRC}^{17}$. However, according to histopathological finding, the lining entirely composed of pseudostratified columnar epithelium with no signs of decapitation secretion ${ }^{3,18}$. Immunohistochemically, CEA is expressed in columnar cells presenting in the superficial layer of pseudostratified epithelium ${ }^{19}$. The presence of myoepithelial cells and decapitation secretion in apocrine hidrocystoma are important in differentiating those two diseases ${ }^{17}$. In our case, we conclude that apocrine hidrocystoma is more appropriate than MRC because CEA was negative and p63, myoepithelial marker, was positive. On the other hand, discrimination from eccrine hidrocystoma is also important. Eccrine hidrocystomas are true retention cysts that histologically are covered by two layers of cuboidal or flattened cells without myoepithelial cells and decapitation secretion. The immunohistochemical markers that are positive in apocrine hidrocystoma are all negative. Clinically, eccrine hidrocystoma can be seen as multiple lesions of the face area and have seasonal variation ${ }^{1,3}$. Sclerosing lymphangitis and acquired lymphangioma are also distinct histologically. Sclerosing lymphangitis shows hypertrophy of lymphatic channels with or without perilymphatic cell infiltration or thrombi. In case of acquired lymphangioma, numerous dilated lymphatic vessels are observed in upper dermis $^{9}$.

The treatment for apocrine hidrocystoma is excision with narrow margins because of the benign nature of the le$\operatorname{sion}^{3}$. Other methods that have shown success include carbon dioxide laser vaporization and laser treatment ${ }^{15}$. In conclusion, although genital apocrine hidrocystoma is rare, we should be considered in the differential diagnosis of a genital cystic lesion. This paper emphasizes the importance of considering this diagnosis when evaluating a cystic lesion in genitalia.

\section{ACKNOWLEDGMENT}

We thank the patient for granting permission to publish this information. 


\section{CONFLICTS OF INTEREST}

The authors have nothing to disclose.

\section{ORCID}

Jeong Won Jo, https://orcid.org/0000-0002-4324-940X

Jung Wook Yang, https://orcid.org/0000-0002-9698-3667

Do Seon Jeong, https://orcid.org/0000-0002-5857-5670

\section{REFERENCES}

1. Kikuchi K, Fukunaga S, Inoue H, Miyazaki Y, Ide F, Kusama K. Apocrine hidrocystoma of the lower lip: a case report and literature review. Head Neck Pathol 2014;8:117-121.

2. Mehregan AH. Apocrine cystadenoma; a clinicopathologic study with special reference to the pigmented variety. Arch Dermatol 1964;90:274-279.

3. Samplaski MK, Somani N, Palmer JS. Apocrine hidrocystoma on glans penis of a child. Urology 2009;73:800-801.

4. Ahmed A, Jones AW. Apocrine cystadenoma. A report of two cases occurring on the prepuce. Br J Dermatol 1969; 81:899-901.

5. Powell RF, Palmer $\mathrm{CH}$, Smith EB. Apocrine cystadenoma of the penile shaft. Arch Dermatol 1977;113:1250-1251.

6. de Dulanto F, Armijo-Moreno M, Camacho Martinez F. [Nodular hidradenoma (apocrine cystadenoma) of the penis]. Ann Dermatol Syphiligr (Paris) 1973;100:417-422. French.

7. Flessati P, Camoglio FN, Bianchi S, Fasoli L, Menghi A. [An apocrine hidrocystoma of the scrotum. A case report]. Minerva Chir 1999;54:87-89. Italian.

8. Glusac EJ, Hendrickson MS, Smoller BR. Apocrine cystade- noma of the vulva. J Am Acad Dermatol 1994;31(3 Pt 1): 498-499.

9. Mataix J, Bañuls J, Blanes M, Pastor N, Betlloch I. Translucent nodular lesion of the penis. Apocrine hidrocystoma of the penis. Arch Dermatol 2006;142:1221-1226.

10. Liu YS, Wang JS, Li TS. A 25-year-old man with a domeshaped translucent nodule on the glans penis. Dermatol Sin 2010;28:177-178.

11. López $\mathrm{V}$, Alonso $\mathrm{V}$, Jordá $\mathrm{E}$, Santonja N. Apocrine hidrocystoma on the penis of a 40-year-old man. Int J Dermatol 2013;52:502-504.

12. Park J, Kim I, Jang HC, Chae IS, Park K, Kim Y, et al. Linear skin-coloured papules on scrotum: a quiz. Apocrine hidrocystoma. Acta Derm Venereol 2015;95:762-763.

13. Taylor D, Juhl ME, Krunic AL, Sidiropoulos M, Gerami P. Apocrine hidrocystoma of the urethral meatus: a case report. Acta Derm Venereol 2015;95:376-377.

14. Vani D, T R D, H B S, M B, Kumar HR, Ravikumar V. Multiple apocrine hidrocystomas: a case report. J Clin Diagn Res 2013;7:171-172.

15. Sarabi K, Khachemoune A. Hidrocystomas--a brief review. MedGenMed 2006;8:57.

16. Ohnishi T, Watanabe S. Immunohistochemical analysis of cytokeratin expression in apocrine cystadenoma or hidrocystoma. J Cutan Pathol 1999;26:295-300.

17. Persec Z, Persec J, Sovic T, Rako D, Bacalja J, Hrgovic Z, et al. Median raphe cyst-clinical report and immunohistochemical analysis. J Clin Exp Dermatol Res 2013;S6:011.

18. Deliktas H, Sahin H, Celik OI, Erdogan O. Median raphe cyst of the penis. Urol J 2015;12:2287-2288

19. Dini M, Baroni G, Colafranceschi M. Median raphe cyst of the penis: a report of two cases with immunohistochemical investigation. Am J Dermatopathol 2001;23:320-324. 